\title{
Postharvest Salicylic Acid Application to Improving Eating Quality and Marketability of Anna Apple Fruits
}

\author{
Enas.A. Tayel ${ }^{1}$ and Naglaa, M.E. Yassien ${ }^{2}$
}

\begin{abstract}
Apples (Cv. Anna) fruit were subjected to salicylic acid at $0.4 \%, 0.8 \%$ and $1.2 \%$ and control (dipped in water). Thereafter, fruits were kept for 15 days continuously at $20{ }^{\circ} \mathrm{C}$ to investigated effect at above mentioned treatments on behaviour of the common cv. apple in Egypt after harvest. The results indicated that salicylic acid treatments at concentration of $0.8 \%$ and $1.2 \%$ had significant effect on reducing weight loss compared with the control. Both concentrations of salicylic acid decreased soluble solid content (SSC), titratable acidity (TA) and maintain the higher values of firmness.
\end{abstract}

The data also revealed that, the storage period advanced TA, firmness and reducing sugars reduced while SSC and weight loss increased in all tested treatments.

\section{INTRODUCTION}

Apples are the natural source of dietary mineral salts, vitamins, antioxidants, fibers, organic acids and sugars. The highest concentration of bioactive substances, including antioxidants, is found in or near the peel, so it is recommended as a dietary supplement (Wolfe and Liux, 2003 and Wolfe et al., 2003).

Apple is a climacteric fruit with a long post-harvest life in cool storage. Losses in fruit quality are mostly due to its relatively high metabolic activity during storage (Fattahi et al., 2010). Salicylic acid (SA) is considered as a plant hormone (Raskin, 1992) because of its role in regulating some aspects of disease resistance in plants. More recently, the involvement of $\mathrm{SA}$ as a single molecule in systemic acquired resistance associated with the production of pathogenesis-related proteins has been extensively shown (Shah, 2003 and Beckers and Spoel, 2006).

Moreover, dietary salicylates from fruit and vegetables are described as bioactive compounds with health care potential (Hooper and Gassily, 2006) and considered as generally recognized as safe.

Literature exists about some beneficial effect of SA treatments in fruit. During kiwifruit ripening, application with acetylsalicylic acid ASA, a derivative of SA, showed down the softening rate of kiwifruit by inhibiting ethylene production and maintaining higher endogenous SA level (Zhang et al., 2003).
On the other hand, SA application either preharvest (Yao and Tian, 2005) or postharvest reduced fungal decay in sweet cherry through induction of the defence resistance system (Chan and Tian, 2006) and stimulation of antioxidant enzymes (Xu and Tian, 2008). In addition, in chilling injury (CI) sensitive fruit, pretreatment with SA reduced chilling injury (CI) in peaches (Wang et al., 2006). The aim of the present study, was to investigate the effects of salicylic acid (SA) on Anna apple fruits quality after harvest by measuring physical and chemical changes during simulated marketability period at $20^{\circ} \mathrm{C}$.

\section{MATERIALS AND METHODS}

The present investigation was carried out during 2008 and 2009 seasons on Anna apple fruits (Malus domestica, Borkb) that harvested from seven years old trees budded on Balady apple rootstock. The trees were grown in sandy soil of private orchard at EL-Nobaria city, EL-Behera Governorate. Trees were spaced at $4 \times 5$ $\mathrm{m}$.

Harvested fruits were packed in field boxes and immediately transported to Postharvest Center, Faculty of Agriculture, Alexandria University.

Sound fruits were selected on the basis of uniformity of size and color. Selected fruits were washed with running tap water and then dried by an electric fan and a sorting was done to recheck the fruits of any defects.

Sound selected fruits were divided into 4 groups each one contained 60 fruits for each treatment, then placed in 3 carton boxes at the dimensions of $50 \times 30 \times 5$ $\mathrm{cm}$ for length, width and height, respectively, each box contained 20 fruits.

Fruits were subjected to the following testal treatments:

1- Fruits were dipped in $0.4 \%$ salicylic acid for 5 minutes and held at $20^{\circ} \mathrm{C}\left(\mathrm{T}_{1}\right)$.

2- Fruits were dipped in $0.8 \%$ salicylic acid for 5 minutes and held at $20^{\circ} \mathrm{C}\left(\mathrm{T}_{2}\right)$.

3- Fruits were dipped in $1.2 \%$ salicylic acid for 5 minutes and held at $20^{\circ} \mathrm{C}\left(\mathrm{T}_{3}\right)$.

4- Fruits were dipped in water (control) for 5 minutes and held at $20^{\circ} \mathrm{C}\left(\mathrm{T}_{4}\right)$.

\footnotetext{
${ }^{1}$ Mamoura Bot. Garden. Alex. Hort. Res. Instit. Agric. Res. Center, Egypt.

${ }^{2}$ Hort. Res. Station, Sabahia, Alex., Hort. Res. Ins., A.R.C. Giza, Egypt.

Received June 20, 2011, Accepted June 29, 2011
} 
Nine apple fruits were taken to determine the initial physio-chemical properties which were followed up in 5 days intervals throughout the experimental period as follows:

\section{1- Physical characteristics:}

\section{1- Fruit weight loss (\%):}

In this experiment, 3 fruits of each replicate for each treatment were initially weighted and labeled. The initial weight of each labeled fruits was recorded to calculate fruit weight loss percent at 7 days intervals throughout the course of the study. The average weight loss percent was calculated for each treatment according to the following equation:

Weight loss $\%=\frac{\text { Initial weight }- \text { Samples weight }}{\text { Initial weight }} \times 100$

\section{2- Fruit Firmness (Ib force):}

Flesh firmness was determined in any given sample by peeling the two opposite sides of the fruit and the firmness of each side was determined by using the Effegi pressure tester with an eight mm plunger (Effegi48011 Alfonsine, Italy).

The average flesh firmness of each fruit sample was calculated from a minimum of 20 readings, fruit firmness was expressed as pounds force.

\section{2- Chemical characteristics:}

Changes of chemical parameters were determined using three fruits for every replicate during the storage period as the previously mentioned intervals as described below.

\section{1- Soluble Solids Content (SSC):}

The soluble solids content (SSC) of fruit juice was determined using a hand refractometer (ATAGo, mod N.IE, Japan) according to A.O.A.C. (1990). The soluble solids content were expressed as percent $(\%)$.

\section{2- Titratable acidity:}

The titratable acidity of fruit juice was determined using five milliliters from the obtained juice for the titration, $0.1 \mathrm{~N}$ sodium hydroxide was used in the presence of phenol phethalein as an indicator according to A.O.A.C (1990).
The titratable acidity was expressed as mg of malic acid for $100 \mathrm{ml}$ of Anna apple fruit juice.

\section{Sugars content $(\%)$ :}

Sugars were extracted from $10 \mathrm{gm}$ of well chopped and mixed flesh of each fruit sample. The extraction was carried out by using distilled water (Loomis and Shull, 1937). Reducing sugars content was determined by the method of Shaffer and Hartman (1921).

The non-reducing sugars were determined by the hydrolysis with sulfuric acid and the total reducing sugars were then determined (Dubois et al., 1956). After that the non-reducing sugars were calculated by the difference between the total and the reducing sugars.

Sugars content was expressed as $\mathrm{mg} / 100 \mathrm{gm}$ fresh weight of fruit flesh. The termination of the experiment was done in the two years of the study when fruit firmness reached around $3 \mathrm{Ib} / \mathrm{inch}^{2}$.

The experimental design was factorial (RCBD) design with three replicates and the data obtained were statistically analyzed according to Snedecor and Cochran (1973).

\section{RESULTS AND DISCUSSION}

\section{1-Physical characteristics:}

\section{1- Fruit weight loss (\%):}

From the tabulated data in Tables 1and 2, it was noticed that weight loss percentages had lower in fruits were dipped in salicylic acid at $0.8 \%\left(\mathrm{~T}_{2}\right)$ compared with all other remaining treatments in both seasons. Similar results were also reported previously by Kazemi et al., 2011 on apple, Shafiee et al. (2010) on strawberry and Sarikhani et al. (2009) on grapes. These results due to salicylic acid (SA) may be attributed to the decrease of respiration through inhibition of ethylene biosynthesis (Srivastava and Dwivedi, 2000). Salicylic acid also decreased in respiration rate and fruit weight loss by closing stoma (Zheng and Zhang, 2004). It is clear that weight loss percentage gradually increased as an average for all treatments by increasing the storage period. The differences among all storage periods were significant in both years of study. Fruit weight loss occurs naturally mainly as a result of water loss from the fruit tissues

Table 1. Effect of postharvest application of salicylic acid on weight loss (\%) of cv. Anna apple fruits in 2008 seasons

\begin{tabular}{lccccc}
\multirow{2}{*}{ Treat. } & \multicolumn{5}{c}{ Storage period (days) } \\
\cline { 2 - 6 } & Initial & $\mathbf{5}$ days & $\mathbf{1 0}$ days & $\mathbf{1 5}$ days & Mean $(\mathbf{A})$ \\
\hline $\mathbf{T}_{\mathbf{1}} \mathbf{0 . 4 \%} \mathbf{~ S A}$ & 0.0 & 2.73 & 4.41 & 6.13 & $3.13 \mathrm{AB}$ \\
\hline $\mathbf{T}_{\mathbf{2}} \mathbf{0 . 8 \%} \mathbf{~ S A}$ & 0.0 & 2.42 & 3.49 & 5.63 & $2.88 \mathrm{~B}$ \\
\hline $\mathbf{T}_{\mathbf{3}}: \mathbf{1 . 2 \%} \mathbf{S A}$ & 0.0 & 2.67 & 4.14 & 6.63 & $3.583 \mathrm{~A}$ \\
\hline $\mathbf{T}_{\mathbf{4}}:$ water & 0.0 & 2.81 & 4.10 & 7.0 & $3.480 \mathrm{~A}$ \\
\hline Mean $(\mathbf{B})$ & $0.0 \mathrm{D}$ & $2.65 \mathrm{C}$ & $4.03 \mathrm{~B}$ & $6.34 \mathrm{~A}$ & \\
\hline
\end{tabular}

*Means followed by the same letters are not statistically different at $\mathrm{P}(0.05)$. 
Table 2. Effect of postharvest application of salicylic acid on weight loss (\%) of cv. Anna apple fruits in 2009 seasons

\begin{tabular}{lccccc}
\hline \multirow{2}{*}{ Treat. } & \multicolumn{5}{c}{ Storage period (days) } \\
\cline { 2 - 6 } & Initial & $\mathbf{5}$ days & $\mathbf{1 0}$ days & $\mathbf{1 5}$ days & Mean $(\mathbf{A})$ \\
\hline $\mathbf{T}_{\mathbf{1}}: \mathbf{0 . 4 \%} \mathbf{S A}$ & 0.0 & 2.67 & 4.12 & 6.14 & $3.233 \mathrm{~A}$ \\
\hline $\mathbf{T}_{\mathbf{2}}: \mathbf{0 . 8 \%} \mathbf{S A}$ & 0.0 & 2.56 & 3.66 & 5.40 & $2.907 \mathrm{~B}$ \\
\hline $\mathbf{T}_{\mathbf{3}}: \mathbf{1 . 2 \%} \mathbf{S A}$ & 0.0 & 2.69 & 4.01 & 5.58 & $3.0733 \mathrm{AB}$ \\
\hline $\mathbf{T}_{\mathbf{4}}:$ water & 0.0 & 2.58 & 3.88 & 6.60 & $3.267 \mathrm{~A}$ \\
\hline Mean $(\mathbf{B})$ & $0.0 \mathrm{D}$ & $2.628 \mathrm{C}$ & $3.920 \mathrm{~B}$ & $5.932 \mathrm{~A}$ & \\
\hline
\end{tabular}

*Means followed by the same letters are not statistically different at $\mathrm{P}(0.05)$.

during storage and partially during respiration process. The later results agree with those reported by Abd ELMigid (1986) on pear and Rasmussen (1990) on apple.

\section{2- Firmness:}

The changes in flesh firmness of apple fruits in the two seasons of the study are presented in Tables 3 and 4 . Generally, all SA treatments maintained flesh firmness of the fruits comparing with the control in both seasons but there were no significant differences among SA treatments. The obtained results herein are in agreement with Yiwei et al. (2008) on apples, Zhang Yu et al. (2003) on kiwifruit. Lijum and Shaohua (2008), Sarikhani et al. (2009) on grapes. All of them confirmed the effect of salicylic acid on firmness and found that salicylic acid can delay the ripening accrued probably through inhibition of ethylene biosynthesis or its action during postharvest ripening. The trend of flesh firmness was decreased with the progress of the storage period in both seasons of the study. As a conclusion, loss in fruits firmness with the progress of storage period is mainly due to decomposition, enzymatic degradation of insoluble protopectins to more simple soluble pectins, solubilization of cell and cell wall contents as a result of the increasing in pectin esterase activity and subsequent development of juiciness and loss in peel and pulp hardness. These results were in agreement with those previously found by many researches such as Ponomarev (1968) and Siddiqui et al. (1996).

\section{2- Chemical characteristics:}

\section{1- Soluble solids contents (SSC):}

From the tabulated data in Tables 5 and 6 it was noticed that soluble solids contents (SSC) had highest in control (dipping in water) compared with all salicylic acid (SA) treatments in both seasons. These results were in line with those reported previously by Yiwei et al. (2008) on apples and AL-Obeed (2010)on Barhee date palm. On the other hand, these results disagreed with Sayyari et al. (2009). They found that there was no significant effect of SA application on soluble solid content in pomegranate fruits.
The data of the present study also pointed out that there was slight increase during 10 days of storage then decreased until the end of the storage period.

These results are supported by Abd EL-Migid (1986) and EL-Seidy (1994) on pears and Mahajan (1994) and Dris (1999) on apples.

\section{2- Titratable acidity (TA):}

The data of the present investigation recorded in Tables 7 and 8 showed TA values of Anna apple, in the first season. The results indicated that there was significantly effect with the treatment of SA at $0.8 \%$ and the control compared with the other two SA concentrations, while in the second season there were significant differences between the fruits dipped in SA at $1.2 \%$ and control compared with the other two SA treatments.

These results are in agreement with those reported by Yiwei et al. (2008) and Sayyari et al. (2009).

The data in the present study also pointed out that there was slight decrease in TA values which could be due to the increase of its consumption in respiration activities as an organic substrate. This result agree with those reported by Chen and Mellenthin (1981), Abd EL-Migid (1986) and EL-Seidy (1994) on pear.

\section{3- Sugars content:}

\subsection{1- Total sugars:}

The data illustrated in Tables 9 and 10 showed the total sugar percentages as affected by salicylic acid dipping. In the first seasons, the total sugars were lower in fruits dipped in salicylic acid (SA) at $1.2 \%$ compared with the other treatments including control. On the other hand, in the second season, fruits dipped in salicylic acid (SA) at the concentration of $0.4 \%$ had lower percentage of total sugars.

These results agree with Yiewi et al. (2008), Liwen and Chen (2005) on banana and AL-Obeed (2010) on date palm. They all found that SA showed positive effects in maintaining membrane integrity and thus delaying ripening process in apple fruits mainly through decreasing oxidative stress and ethylene production. 
Table 3. Effect of postharvest application of salicylic acid on firmness ( $\left.\mathrm{Ib} / \mathrm{in}^{2}\right)$ of $\mathrm{cv}$. Anna apple fruits in 2008 seasons

\begin{tabular}{lccccc}
\hline \multirow{2}{*}{ Treat. } & \multicolumn{5}{c}{ Storage period (days) } \\
\cline { 2 - 6 } & Initial & $\mathbf{5}$ days & $\mathbf{1 0}$ days & $\mathbf{1 5}$ days & Mean $(\mathbf{A})$ \\
\hline $\mathbf{T}_{\mathbf{1}}: \mathbf{0 . 4 \%} \mathbf{~ S A}$ & 9.27 & 7.41 & 6.21 & 4.01 & $6.725 \mathrm{AB}$ \\
\hline $\mathbf{T}_{\mathbf{2}} \mathbf{0 . 8 \%} \mathbf{~ S A}$ & 9.27 & 7.17 & 5.43 & 5.22 & $6.5225 \mathrm{AB}$ \\
\hline $\mathbf{T}_{\mathbf{3}}: \mathbf{1 . 2 \%} \mathbf{~ S A}$ & 9.27 & 7.85 & 5.56 & 4.62 & $6.825 \mathrm{~A}$ \\
\hline $\mathbf{T}_{\mathbf{4}}:$ water & 9.27 & 6.96 & 5.32 & 3.43 & $6.21 \mathrm{~B}$ \\
\hline Mean $(\mathbf{B})$ & $9.27 \mathrm{~A}$ & $7.347 \mathrm{~B}$ & $5.54 \mathrm{C}$ & $4.07 \mathrm{D}$ & \\
\hline * Means followed by the
\end{tabular}

Table 4. Effect of postharvest application of salicylic acid on firmness (Ib/ in $\left.{ }^{2}\right)$ of $\mathrm{cv}$. Anna apple fruits in 2009 seasons

\begin{tabular}{lccccc}
\multicolumn{1}{c}{ Treat. } & \multicolumn{5}{c}{ Storage period (days) } \\
\cline { 2 - 6 } & Initial & $\mathbf{5}$ days & $\mathbf{1 0}$ days & $\mathbf{1 5}$ days & Mean $(\mathbf{A})$ \\
\hline $\mathbf{T}_{\mathbf{1}}: \mathbf{0 . 4 \%} \mathbf{~ S A}$ & 10.33 & 8.26 & 6.25 & 3.61 & $7.11 \mathrm{~A}$ \\
\hline $\mathbf{T}_{\mathbf{2}} \mathbf{0 . 8 \%} \mathbf{S A}$ & 10.33 & 7.43 & 5.36 & 4.35 & $6.86 \mathrm{AB}$ \\
\hline $\mathbf{T}_{\mathbf{3}}: \mathbf{1 . 2 \%} \mathbf{S A}$ & 10.33 & 7.69 & 5.91 & 4.03 & $6.99 \mathrm{AB}$ \\
\hline $\mathbf{T}_{\mathbf{4}}:$ water & 10.33 & 7.3 & 5.03 & 3.63 & $6.572 \mathrm{~B}$ \\
\hline Mean $(\mathbf{B})$ & $10.33 \mathrm{~A}$ & $7.42 \mathrm{~B}$ & $5.89 \mathrm{C}$ & $3.92 \mathrm{D}$ & \\
\hline
\end{tabular}

* Means followed by the same letters are not statistically different at $\mathrm{P}(0.05)$.

Table 5. Effect of postharvest application of salicylic acid on soluble solids content (SSC\%) of cv. Anna apple fruits in 2008 seasons

\begin{tabular}{lccccc}
\hline \multirow{2}{*}{ Treat. } & \multicolumn{5}{c}{ Storage period (days) } \\
\cline { 2 - 6 } & Initial & $\mathbf{5}$ days & $\mathbf{1 0}$ days & $\mathbf{1 5}$ days & Mean $(\mathbf{A})$ \\
\hline $\mathbf{T}_{\mathbf{1}}: \mathbf{0 . 4 \%} \mathbf{~ S A}$ & 12.26 & 12.66 & 11.96 & 11.8 & $12.10 \mathrm{AB}$ \\
\hline $\mathbf{T}_{\mathbf{2}} \mathbf{0 . 8 \%} \mathbf{~ S A}$ & 12.26 & 11.6 & 11.52 & 11.46 & $11.93 \mathrm{~B}$ \\
\hline $\mathbf{T}_{\mathbf{3}}: \mathbf{1 . 2 \%} \mathbf{~ S A}$ & 12.26 & 12.2 & 12.33 & 11.6 & $12.10 \mathrm{AB}$ \\
\hline $\mathbf{T}_{\mathbf{4}}:$ water & 12.26 & 12.86 & 12.63 & 11.73 & $12.46 \mathrm{~A}$ \\
\hline Mean $(\mathbf{B})$ & $12.26 \mathrm{~A}$ & $12.33 \mathrm{~A}$ & $12.36 \mathrm{~A}$ & $11.65 \mathrm{~B}$ & \\
\hline
\end{tabular}

* Means followed by the same letters are not statistically different at $\mathrm{P}(0.05)$.

Table 6. Effect of postharvest application of salicylic acid on soluble solids content (SSC\%) of cv. Anna apple fruits in 2009 seasons

\begin{tabular}{lccccc}
\hline \multirow{2}{*}{ Treat. } & \multicolumn{5}{c}{ Storage period (days) } \\
\cline { 2 - 6 } & Initial & $\mathbf{5}$ days & $\mathbf{1 0}$ days & $\mathbf{1 5}$ days & Mean (A) \\
\hline $\mathbf{T}_{\mathbf{1}} \mathbf{0} \mathbf{0 . 4 \%} \mathbf{~ S A}$ & 12.0 & 11.6 & 12.13 & 11.46 & $11.80 \mathrm{~B}$ \\
\hline $\mathbf{T}_{\mathbf{2}} \mathbf{0 . 8 \%} \mathbf{~ S A}$ & 12.0 & 11.86 & 12.6 & 11.46 & $11.98 \mathrm{AB}$ \\
\hline $\mathbf{T}_{\mathbf{3}}: \mathbf{1 . 2 \%} \mathbf{S A}$ & 12.0 & 12.2 & 12.33 & 11.8 & $12.08 \mathrm{AB}$ \\
\hline $\mathbf{T}_{\mathbf{4}}:$ water & 12.0 & 13.2 & 12.00 & 12.06 & $12.39 \mathrm{~A}$ \\
\hline Mean $(\mathbf{B})$ & $12.0 \mathrm{AB}$ & $12.21 \mathrm{~A}$ & $12.26 \mathrm{~A}$ & $11.70 \mathrm{~B}$ & \\
\hline
\end{tabular}

* Means followed by the same letters are not statistically different at $\mathrm{P}(0.05)$.

Table 7. Effect of postharvest application of salicylic acid on titratable acidity content (\%) of cv. Anna apple fruits in 2008 seasons

\begin{tabular}{lccccc}
\hline \multirow{2}{*}{ Treat. } & \multicolumn{5}{c}{ Storage period (days) } \\
\cline { 2 - 6 } & Initial & $\mathbf{5}$ days & $\mathbf{1 0}$ days & $\mathbf{1 5}$ days & Mean $(\mathbf{A})$ \\
\hline $\mathbf{T}_{\mathbf{1}}: \mathbf{0 . 4 \%}$ SA & 0.814 & 0.707 & 0.783 & 0.737 & $0.760 \mathrm{~B}$ \\
\hline $\mathbf{T}_{\mathbf{2}} \mathbf{0 . 8 \%} \mathbf{S A}$ & 0.814 & 0.756 & 0.769 & 0.781 & $0.780 \mathrm{~A}$ \\
\hline $\mathbf{T}_{\mathbf{3}}: \mathbf{1 . 2 \%} \mathbf{S A}$ & 0.814 & 0.778 & 0.748 & 0.748 & $0.772 \mathrm{AB}$ \\
\hline $\mathbf{T}_{\mathbf{4}}:$ water & 0.814 & 0.774 & 0.762 & 0.767 & $0.779 \mathrm{~A}$ \\
\hline Mean $(\mathbf{B})$ & $0.814 \mathrm{~A}$ & $0.754 \mathrm{~B}$ & $0.765 \mathrm{~B}$ & $0.758 \mathrm{~B}$ & \\
\hline
\end{tabular}

* Means followed by the same letters are not statistically different at $\mathrm{P}(0.05)$. 
Table 8. Effect of postharvest application of salicylic acid on titratable acidity content (\%) of cv. Anna apple fruits in 2009 seasons

\begin{tabular}{lccccc}
\hline \multirow{2}{*}{ Treat. } & \multicolumn{5}{c}{ Storage period (days) } \\
\cline { 2 - 6 } & Initial & $\mathbf{5}$ days & $\mathbf{1 0}$ days & $\mathbf{1 5}$ days & Mean $(\mathbf{A})$ \\
\hline $\mathbf{T}_{\mathbf{1}} \mathbf{0} \mathbf{0 . 4 \%} \mathbf{S A}$ & 0.787 & 0.742 & 0.787 & 0.737 & $0.758 \mathrm{C}$ \\
\hline $\mathbf{T}_{\mathbf{2}} \mathbf{0 . 8 \%} \mathbf{S A}$ & 0.787 & 0.787 & 0.769 & 0.748 & $0.770 \mathrm{BC}$ \\
\hline $\mathbf{T}_{\mathbf{3}}: \mathbf{1 . 2 \%} \mathbf{S A}$ & 0.787 & 0.778 & 0.767 & 0.761 & $0.773 \mathrm{AB}$ \\
\hline $\mathbf{T}_{\mathbf{4}}:$ water & 0.787 & 0.771 & 0.767 & 0.774 & $0.774 \mathrm{~A}$ \\
\hline Mean $(\mathbf{B})$ & $0.787 \mathrm{~A}$ & $0.772 \mathrm{~B}$ & $0.763 \mathrm{~B}$ & $0.755 \mathrm{C}$ & \\
\hline * Means followed by the same letters are not statistically different at $\mathrm{P}(0.05)$. & &
\end{tabular}

Table .9. Effect of postharvest application of salicylic acid on total sugars (\%) of cv. Anna apple fruits in 2008 seasons

\begin{tabular}{lccccc}
\multicolumn{1}{c}{ Treat. } & \multicolumn{5}{c}{ Storage period (days) } \\
\cline { 2 - 6 } & Initial & $\mathbf{5}$ days & $\mathbf{1 0}$ days & $\mathbf{1 5}$ days & Mean $(\mathbf{A})$ \\
\hline $\mathbf{T}_{\mathbf{1}}: \mathbf{0 . 4 \%}$ SA & 9.97 & 9.89 & 10.85 & 9.92 & $10.10 \mathrm{~A}$ \\
\hline $\mathbf{T}_{\mathbf{2}} \mathbf{0 . 8 \%} \mathbf{S A}$ & 9.97 & 9.10 & 10.38 & 9.78 & $9.852 \mathrm{AB}$ \\
\hline $\mathbf{T}_{\mathbf{3}}: \mathbf{1 . 2 \%}$ SA & 9.97 & 9.44 & 9.62 & 9.33 & $9.592 \mathrm{~B}$ \\
\hline $\mathbf{T}_{\mathbf{4}}:$ water & 9.97 & 9.38 & 9.72 & 10.39 & $9.868 \mathrm{AB}$ \\
\hline Mean $(\mathbf{B})$ & $9.97 \mathrm{~A}$ & $9.45 \mathrm{~B}$ & $10.14 \mathrm{~A}$ & $9.84 \mathrm{AB}$ & \\
\hline
\end{tabular}

* Means followed by the same letters are not statistically different at $\mathrm{P}(0.05)$.

Table 10. Effect of postharvest application of salicylic acid on total sugars (\%) of cv. Anna apple fruits in 2009 seasons

\begin{tabular}{lccccc}
\multicolumn{1}{c}{ Treat. } & \multicolumn{5}{c}{ Storage period (days) } \\
\cline { 2 - 6 } & Initial & $\mathbf{5}$ days & $\mathbf{1 0}$ days & $\mathbf{1 5}$ days & Mean $(\mathbf{A})$ \\
\hline $\mathbf{T}_{\mathbf{1}}: \mathbf{0 . 4 \%} \mathbf{S A}$ & 10.73 & 9.61 & 9.82 & 9.4 & $9.892 \mathrm{~B}$ \\
\hline $\mathbf{T}_{\mathbf{2}}: \mathbf{0 . 8 \%} \mathbf{~ S A}$ & 10.73 & 9.11 & 11.12 & 9.84 & $10.203 \mathrm{AB}$ \\
\hline $\mathbf{T}_{\mathbf{3}}: \mathbf{1 . 2 \%} \mathbf{S A}$ & 10.73 & 9.02 & 11.68 & 10.87 & $10.578 \mathrm{~A}$ \\
\hline $\mathbf{T}_{\mathbf{4}}:$ water & 10.73 & 9.25 & 11.09 & 10.15 & $10.3067 \mathrm{~A}$ \\
\hline Mean $(\mathbf{B})$ & $10.73 \mathrm{~A}$ & $9.25 \mathrm{C}$ & $10.93 \mathrm{~A}$ & $10.06 \mathrm{~B}$ & \\
\hline
\end{tabular}

* Means followed by the same letters are not statistically different at $\mathrm{P}(0.05)$.

The total sugars percentage of Anna apple fruits increased slightly until 10 days then decreased till the end of each seasons. This result may be to the climacteric character of apple fruits (Fattahi et al., 2010).

\subsection{2- Reducing sugars:}

The data in Tables 11 and 12 showed that there were no significant differences among all treatments belong to reducing sugar percentages in the two seasons. These results were in agreement with those obtained by ALObeed (2010) on dates and Aljuburi et al. (2000) on date palm. The data in the present study also pointed out that there were significant decrease in reducing sugars in both seasons. These results were in agreement with those of Tayel (2001) and EL-Seidy (2000) on peaches.

\subsection{3- Non-Reducing sugars:}

The data of the present investigation in Tables 13 and 14 showed the non reducing sugars values of Anna apple fruits as affected by salicylic acid treatments. In the first season, the fruits dipped in salicylic acid at $1.2 \%\left(\mathrm{~T}_{3}\right)$ had the lowest non reducing sugars values as compared with all other remaining treatments. In the second season, the treatment of salicylic acid at $0.4 \%$ $\left(\mathrm{T}_{1}\right)$ had the lowest non reducing sugars percentages.

Table 11. Effect of postharvest application of salicylic acid on reducing sugars (\%) of $\mathrm{cv}$. Anna apple fruits in 2008 seasons

\begin{tabular}{lccccc}
\multicolumn{1}{c}{ Treat. } & \multicolumn{4}{c}{ Storage period (days) } \\
\cline { 2 - 6 } & Initial & $\mathbf{5}$ days & $\mathbf{1 0}$ days & $\mathbf{1 5}$ days & Mean (A) \\
\hline $\mathbf{T}_{\mathbf{1}}: \mathbf{0 . 4 \%} \mathbf{S A}$ & 5.73 & 5.39 & 6.06 & 4.18 & $5.34 \mathrm{~A}$ \\
\hline $\mathbf{T}_{\mathbf{2}}: \mathbf{0 . 8 \%} \mathbf{~ S A}$ & 5.73 & 5.47 & 5.23 & 5.09 & $5.38 \mathrm{~A}$ \\
\hline $\mathbf{T}_{\mathbf{3}}: \mathbf{1 . 2 \%} \mathbf{S A}$ & 5.73 & 5.59 & 5.72 & 5.24 & $5.39 \mathrm{~A}$ \\
\hline $\mathbf{T}_{\mathbf{4}}:$ water & 5.73 & 5.4 & 5.28 & 5.15 & $5.57 \mathrm{~A}$ \\
\hline Mean $(\mathbf{B})$ & $5.73 \mathrm{~A}$ & $5.465 \mathrm{~B}$ & $5.57 \mathrm{AB}$ & $4.91 \mathrm{C}$ \\
\hline
\end{tabular}

* Means followed by the same letters are not statistically different at $\mathrm{P}(0.05)$. 
Table 12. Effect of postharvest application of salicylic acid on reducing sugars (\%) of $\mathrm{cv}$. Anna apple fruits in 2009 seasons

\begin{tabular}{lccccc}
\hline \multicolumn{1}{c}{ Treat. } & Initial & $\mathbf{5}$ days & $\mathbf{1 0}$ days & $\mathbf{1 5}$ days & Mean (A) \\
\cline { 2 - 6 } & 5.79 & 5.41 & 5.46 & 5.26 & $5.47 \mathrm{~A}$ \\
\hline $\mathbf{T}_{\mathbf{1}}: \mathbf{0 . 4 \%} \mathbf{~ S A}$ & 5.79 & 6.40 & 5.70 & 5.52 & $5.57 \mathrm{~A}$ \\
\hline $\mathbf{T}_{\mathbf{2}}: \mathbf{0 . 8 \%} \mathbf{~ S A}$ & 5.79 & 6.37 & 5.1 & 5.00 & $5.31 \mathrm{~A}$ \\
\hline $\mathbf{T}_{\mathbf{3}}: \mathbf{1 . 2 \%} \mathbf{~ S A}$ & 5.79 & 6.30 & 5.6 & 5.33 & $5.50 \mathrm{~A}$ \\
\hline $\mathbf{T}_{\mathbf{4}}:$ water & $5.79 \mathrm{~A}$ & $5.375 \mathrm{~B}$ & $5.45 \mathrm{~B}$ & $5.260 \mathrm{~B}$ & \\
\hline Mean $(\mathbf{B})$ & Means followed by the same letters are not statistically different at $\mathrm{P}(0.05)$. & &
\end{tabular}

Table 13. Effect of postharvest application of salicylic acid on non-reducing sugars (\%) of cv. Anna apple fruits in 2008 seasons

\begin{tabular}{lccccc}
\hline \multirow{2}{*}{ Treat. } & \multicolumn{5}{c}{ Storage period (days) } \\
\cline { 2 - 6 } & Initial & $\mathbf{5}$ days & $\mathbf{1 0}$ days & $\mathbf{1 5}$ days & Mean (A) \\
\hline $\mathbf{T}_{\mathbf{1}}: \mathbf{0 . 4 \%} \mathbf{~ S A}$ & 4.15 & 4.51 & 4.80 & 5.69 & $4.792 \mathrm{~A}$ \\
\hline $\mathbf{T}_{\mathbf{2}} \mathbf{0 . 8 \%} \mathbf{~ S A}$ & 4.15 & 3.96 & 4.82 & 4.85 & $4.449 \mathrm{AB}$ \\
\hline $\mathbf{T}_{\mathbf{3}}: \mathbf{1 . 2 \%} \mathbf{S A}$ & 4.15 & 3.84 & 3.89 & 4.09 & $3.997 \mathrm{~B}$ \\
\hline $\mathbf{T}_{\mathbf{4}}:$ water & 4.15 & 4.10 & 4.11 & 5.25 & $4.046 \mathrm{~B}$ \\
\hline Mean $(\mathbf{B})$ & $4.15 \mathrm{~B}$ & $4.107 \mathrm{~B}$ & $4.409 \mathrm{~B}$ & $4.972 \mathrm{~A}$ & \\
\hline
\end{tabular}

* Means followed by the same letters are not statistically different at $\mathrm{P}(0.05)$.

Table 14. Effect of postharvest application of salicylic acid on non-reducing sugars (\%) of cv. Anna apple fruits in 2009 seasons

\begin{tabular}{lccccc}
\hline \multicolumn{1}{c}{ Treat. } & \multicolumn{5}{c}{ Storage period (days) } \\
\cline { 2 - 6 } & Initial & $\mathbf{5}$ days & $\mathbf{1 0}$ days & $\mathbf{1 5}$ days & Mean $(\mathbf{A})$ \\
\hline $\mathbf{T}_{\mathbf{1}}: \mathbf{0 . 4 \%} \mathbf{S A}$ & 4.94 & 4.21 & 4.39 & 4.15 & $4.423 \mathrm{~B}$ \\
\hline $\mathbf{T}_{\mathbf{2}}: \mathbf{0 . 8 \%} \mathbf{~ S A}$ & 4.94 & 4.83 & 5.48 & 4.33 & $4.698 \mathrm{~B}$ \\
\hline $\mathbf{T}_{\mathbf{3}}: \mathbf{1 . 2 \%} \mathbf{S A}$ & 4.94 & 3.65 & 6.57 & 5.86 & $5.26 \mathrm{~A}$ \\
\hline $\mathbf{T}_{\mathbf{4}}: \mathbf{w a t e r}$ & 4.94 & 4.19 & 5.39 & 4.56 & $4.772 \mathrm{~B}$ \\
\hline Mean $\mathbf{( B )}$ & $4.94 \mathrm{~B}$ & $4.022 \mathrm{C}$ & $5.46 \mathrm{~A}$ & $4.72 \mathrm{~B}$ & \\
\hline
\end{tabular}

* Means followed by the same letters are not statistically different at $\mathrm{P}(0.05)$.

These results agreement with those obtained by both AL-Obeed (2010) and Aljuburi et al. (2000) on date palm fruits. Non reducing sugars percentages of Anna apple fruit had inconsistent trend in two seasons. These results were partially supported by Tayel (2001) and EL-Seidy (2000).

\section{CONCLUSION}

From the results of the present study and related discussion it can be concluded that salicylic acid treatments resulted in lower soluble solids content, sugars content, titratable acidity, weight loss and maintained a relatively higher firmness. The results suggested that SA shows positive effects in delaying ripening process in Anna apple fruits.

\section{REFERENCES}

A.O.A.C. (1990). Official methods of Analysis, $15^{\text {th }} \mathrm{Ed}$. Association of Official Analytical Chemists, Inc. USA.

Abd EL-Migid, M.B. (1986). Postharvest physiological studies on LeConte and Kiefer pear fruits stored at different temperature. Ph.D.Thesis, Alexandria University. Alexandria, Egypt.
Aljuburi, H.J., H.H. AL-Masry and S.A. AL-Muhanna (2000). Fruit characteristics and productivity of date palm trees (Phoenix dactylifera, L.) as affected by some growth regulators. Hort. Sci. 35: 476- 477.

AL-Obeed, R.S. (2010). Improving fruit quality, marketability and storage ability of Barhee date palm. World applied Science Journal 9(6): 630-637.

Beckers, G.J.M. and S.H. Spoel (2006). Fine-tuning plant defence signaling: Salicylate versus das monate. Plant Biol. 8, 1-10.

Chan, Z. and S. Tian (2006). Induction of $\mathrm{H}_{2} \mathrm{O}_{2}$ metabolizing enzymes and total protein synthesis by antagonist and salicylic acid in harvested sweet cherry fruit. Postharvest Biol. Technol. 39, 314-320.

Chen, P.M. and W.M. Mellenthin (1981). Effects of harvest date on ripening capacity and postharvest life of d,Anjou pears. J. Amer Soc. Hort. Sci. 106 (1): 38- 42.

Dris, R. (1999). Variation in the storage life of Lobo, Aroma, Red Atlas and Raike apples during three years. Acta. Hort., 485: 133- 139 (C.F.Hort. Abst., 69 (10): 8393, 1999). 
Dubois, M.; K.A. Gilles, J.K. Haniltion, P.A. Robers and F.Smith (1956).Colorimetric method for determination of sugar and related substance. Anal. Chem 28 (3): 350- 356.

EL-Seidy, R.M. (1994). Physiological studies on cooling and refrigerated storage of fresh Le Conte pears. M.Sc. Thesis, Alexandria University, Alexandria, Egypt

EL-Seidy, R.M. (2000). Postharvest prestorage calcium treatments in relation to quality changes and storage ability of peaches. Ph.D. Thesis, Alex. Univ., Alex., Egypt.

Fattahi, J.R. Fifall and M. Babri (2010). Postharvest quality of kiwifruit (Actindco delicious Cv. Hyward) affected by prestorage application of salicylic acid. S. Western J. Hortic. Biol. Environ. 1: 175- 186.

Hooper, L. and A. Gassidy (2006). A review of the health care potential of bioactive compounds. J. Sci. Food Agric. 86, 1805- 1813.

Kazami M., M. Aran and S.Zamani (2011). Effect of salicylic acid treatments on quality characteristics of apple fruits during storage. American Journal of Plant Physiology. Volume 6, Issue, 2 page, 113- 119.

Lijum, W. and Li. Shaohua (2008). Role of salicylic acid in posthavest physiology. Fresh produce, 2 No:1,2 (pp.1-5).

Liwen Shaoyyuanzhi and Chen Weixin (2005). Effects of salicylic acid on quality of banana after harvest. Chinese Agricultural Science. Bulletin (2): 1-4.

Loomis, W.E. amd C.A. Shull (1937). Methods in plant physiology. McGraw-Hill Bool Co., Inc.

Mahajan, B.V.C (1994). Biological and enzymatic changes in apple during cold storage. J. Fd. Sci. Tech., 31(2); 142144 (C.F. Hort.Abst., 65(3): 1853, 1995).

Ponomarev, P.F. (1968). Changes in content of pectin and in activities of pectolytic enzymes during ripening and storage of pears. Tovarovedenie 3: 6-10 (C.F. fed. Sci. Tech. Abst., 2(10): 1092, 1972).

Raskin, I. (1992). Salicylic, a new plant hormone. Plant Physiol. 99, 799- 803.

Rasmussen, P.M. (1990). Storage experiments with apples 1984-89. Tidsskift for planteavl, 94(1): 39-49. (C.F. Hort. Abst., 61(6): 1756, 1991).

Sarikhani, H., R. Sasani-Homa and D. Barkhshi (2009). Effect of salicylic acid and $\mathrm{SO}_{2}$ ped on storage life and phenolic contents of grape (Vitis vinifera, L.) bid ANEH seed' and Bid ANEH (Hermez) Acta/2 ISHS Acta Horticulture 877: 70. Interanational Postharvest Symposium.

Sayyari, M., M. Bablars.Kalantaris, M. Serrano and D. Velero (2009). Effect of salicylic acid treatment on reducing chilling injury in stored pomegranates. Postharvest Biol. and Tech., 53: 152-154.
Shaffer, P.A. and A.F. Hartman (1921). The iodometric determination of copper and its use in sugar analysis. J. Biol. Chem., 45: 396.

Shafiee, M., T. Staghava and M. Babalar (2010). Addition of salicylic acid nutrient solution combined with postharvest treatments (hot water-salicylic acid and calcium dipping) improved postharvest fruit quality of strawberry. Scientia Horticulturae, 124 (Issue 1, 26: 40-45).

Shah, J. (2003). The salicylic acid loop in plant defence. Curr. Opin Plant Biol. 6, 365- 371.

Siddiqui, S., A. Brackmann, J. Sterif and Bangenrth (1996). Controlled atmosphere storage of apples: Cell wall compostion and fruit softening. J. Hort. Sci. 71(4): 613620 (C.F. Hort. Abst., 66(11): 9219, 1996).

Snedecor, G.W. and W.G. Cochran (1973). Statistical Methods. $6^{\text {th }}$ ed. The lowa state. Press, Lowa, USA.

Srivastava, M.K. and U.N. Dwivedi (2000) Delayed ripening of banana fruit by salcylic acid. Plant. Sci., 158 (1-2): 8796.

Tayel, E.A. (2001). Non-chemical postharvest treatments to maintain fruit quality and improve storage ability of three peach cultivars grown in West Coast Region of Egypt. Ph.D. Thesis, Alex. Univ., Alex., Egypt.

Wang, L., S. Chen, W. Kong, S. Li and D.D. Archbold (2006). Salicylic acid pre treatment alleviates chilling injury and affects the antioxidant system and heat stock proteins of peaches during cold storage. Postharvest Biol. Technol., 41, 244-251.

Wolfe, K. and R.H. Liux(2003). Apple peels as a value-added food ingredient. J. Agric. Food Chem., 51: 1676- 1683.

Wolfe, K., X. Wu and R.H. Liux (2003). Anoxioxidant activity of apple peels. J. Agric food Chem., 51: 609-614.

$\mathrm{Xu}, \mathrm{X}$. and S. Tian (2008). Salicylic acid alleviated pathogeninduced oxidative stress in harvested sweet cherry fruit. Postharvest Biol. Technol. 49, 379-385.

Yao, H. and S. Tian (2005). Effect of pre-harvest application of salicylic acid or methyl Jasmonate on including disease resistance of sweet cherry fruit in storage. Postharvest Biol. Technol. 35, 253-262.

Yiwei, Mo, DeqiangGong. Guobinliang RuihongHan, JianghuiXie and Weicai, Li (2008). Enhanced preservation effects of sugar apple fruits by salicylic acid treatment during post-harvest storage. J. Sci. Food Agric. 88: 26932699.

Zhang, Yu, K.Chen, Sh. Zhang and I. Ferguson (2003). The role of salicylic acid in postharvest ripening of kiwi fruit. Postharvest Biology and Technology 28: 67-74.

Zheng, Y and Q. Zhang (2004). Effects of polyamines and salicylic acid in postharvest storage of ponkau mandonn. Acta. Hortic., 632, 317-320. 


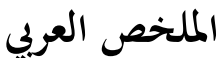

معاملة ثمار التفاح أنا بعد الحصاد بحمض السلسليك وذلك لتحسين كل من الجودة الأكلية والقابلية

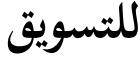

$$
\begin{aligned}
& \text { إيناس عبد العزيز طايل، نجلاء يُمَّمَ عبد الرحيم }
\end{aligned}
$$

1 بثمار التى عوملت بحامض السلسليك بتركيزى 0.8\%، 1.2 \%

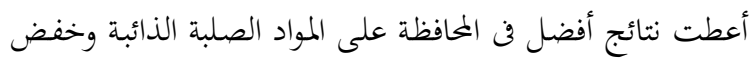

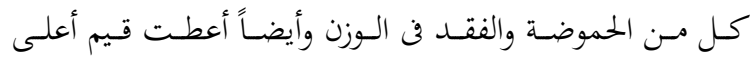

للصلابة.

2 كــان هنـاك إنخفـاض معنسوى في صـابة الثمسار والحموضــة

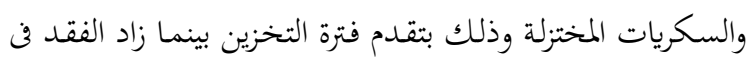

$$
\text { الوزن وزادت المواد الصلبة الذائبة ولكنها قلت فن فاية الفترة. }
$$

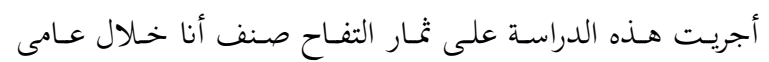

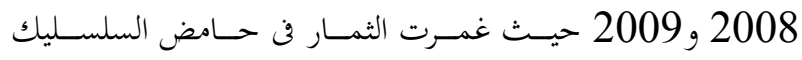
بتركيزات 0.4\%، 0.8\%، 1.2\% ملمدة خمس دقائق، هذا بالإضافة

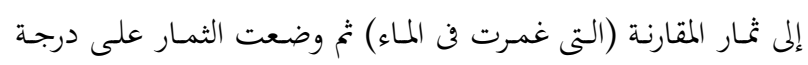

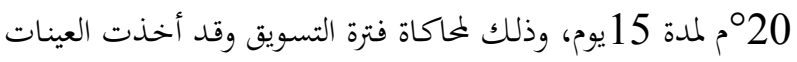
كل 5 أيام ثم قدرت الصفات الطبيعية والكيمائية للثمار. وأشارت النتائج إلى ما يلى: 